\title{
Canine Leptospirosis Serology in Southern Mexico City
}

\author{
Ignacio Martínez-Barbabosa', Edubiel Arturo Alpizar-Sosa ${ }^{1}$, \\ Dolores Guadalupe Gavaldón-Rosas ${ }^{2}$, Luís Pedro Moles-Cervantes ${ }^{2}$, \\ Marcia Gutiérrez Cárdenas ${ }^{1}$, Rafael García-González ${ }^{3}$, \\ Michael Shea4, Ana María Fernández-Presas ${ }^{3 *}$
}

\begin{abstract}
${ }^{1}$ Health Attention Department, Human Parasitology Laboratory, Universidad Autónoma Metropolitana-Xochimilco, México DF, México
${ }^{2}$ Animal and Agriculture Production Department, Universidad Autónoma Metropolitana-Xochimilco, México DF, México

${ }^{3}$ Microbiology and Parasitology Department, School of Medicine, Universidad Autónoma de México, México DF, México

${ }^{4}$ Education and Communication Department, Universidad Autónoma Metropolitana-Xochimilco, México DF, México

Email: ^presas@unam.mx
\end{abstract}

How to cite this paper: Martínez-Barbabosa, I., Alpizar-Sosa, E.A., Gavaldón-Rosas, D.G., Moles-Cervantes, L.P., Cárdenas, M.G., García-González, R., Shea, M. and Fernández-Presas, A.M. (2016) Canine Leptospirosis Serology in Southern Mexico City. Open Journal of Medical Microbiology, 6, 171-180.

http://dx.doi.org/10.4236/ojmm.2016.64022

Received: November 3, 2016

Accepted: December 18, 2016

Published: December 21, 2016

Copyright $\odot 2016$ by authors and Scientific Research Publishing Inc. This work is licensed under the Creative Commons Attribution International License (CC BY 4.0).

http://creativecommons.org/licenses/by/4.0/
Abstract

Background: Leptospirosis is an important zooanthroponotic disease spread worldwide which infection is recognized as a re-emergent disease. Leptospirosis is a systemic disease of humans and domestic animals, mainly dogs, cattle and swine, characterized by fever, renal and hepatic insufficiency, pulmonary manifestations and reproductive failure. Objective: To study the seroprevalence of anti-Leptospira antibodies in an urban canine population. Materials and Methods: The study was performed in March 2014 in stray dogs that had been captured in the districts of Coyoacan, Iztapalapa, Iztacalco and Benito Juarez in Mexico City; 117 dogs were analyzed, from each of which $5 \mathrm{ml}$ of blood were obtained. Serology was performed using a MAT test (Microscopic Agglutination Test), finding that the antigens corresponded to 13 serotypes of Leptospirainterrogans. Three age groups were formed: Group 1) younger than a year $(n=28)$, Group 2) 1 to 6 years $(n=75)$, and Group 3$)$ older than 6 years $(n=14)$. Results: Of the analyzed sera, $28.2 \%$ were seropositive to one or more Leptospira serotypes, $74 \%$ of the positive seracoagglutinated with two or more serotypes. The most frequent serotypes were: Canicola, Icterohaemorrhagiae and Portland-vere. Serotypes Canicola, Pyrogenes, and Bratislava resulted statistically significant $(\mathrm{p}<0.001)$. The presence of anti-Leptospira antibodies in the blood of animals of 1 to 6 years resulted with a $\mathrm{p}<0.001$. The sera from Iztapalapa reacted to nine serotypes. Conclusion: The $28.2 \%$ of seropositivity indicates Leptospira transmission in the canine population that was studied could exhibit a potential public health risk. 


\section{Keywords}

Leptospira, Leptospirosis, Canicola, Icterohaemorrhagiae, Dogs

\section{Introduction}

Leptospirosis is a globally distributed bacterial zoonotic disease and a serious health hazard around the world caused by pathogenic spirochaetes of the Leptospira genus that affects many wild and domestic animal species, such as rats, dogs, pigs, bovines, which are reservoirs, disseminating agents and infection sources for humans [1]-[5].

Infected dogs and rats are the main source of infection for humans [6]. Serologic tests conducted on canine population in different urban environments report a $24.9 \%$ seroprevalence in Michigan, USA. [7], 29.4\% in Milan, Italy [8], 10.5\% in Itapema, Brazil [9], $41.1 \%$ in Cali, Colombia [10], 14.6\% in Trinidad and Tobago [11], and 22\% in Guelph, Canada [12]. The most common serotypes in urban environments are: Canicola, Icterohaemorrhagiae, Grippotyphosa, and Pomona [6] [10] [12] [13]. Previous studies performed in Mexico City report serologic frequencies of $22 \%$ to $76.6 \%$, with Pomona, Canicola and Icterohaemorragiae as the most common serovars (Rivera et al., 1999; Luna et al., 2004). Infected animals eliminate the spirochaetes through urine for months or years, and occasionally through vaginal secretions, thus contaminating soils and water [13] [14] [15].

Leptospirosis can be found in dogs of any age, predominantly in males, probably due to their sniffing habits and licking female's genitalia. The bacterium enters the body through the nasal and oral mucosa, conjunctiva or through open skin wounds. Leptospira is capable of producing severe renal and hepatic disease in the infected host; it can produce a rupture of erythrocytes and obstructive hepatitis, which gives mucous membranes the characteristic yellow color. The clinical outcome varies and depends on the animal's age, immunologic state and on the serovar's virulence. Diagnosing canine leptospirosis is not easy given that leptospiras can affect multiple organ systems, resulting in an extensive variety of clinical presentations, which range from minor to severe and frequently become chronic and without a characteristic symptomatology. The diagnosis is only confirmed once the bacterium is identified or isolated in clinical tests and/or shows high levels of anti-Leptospira antibodies, indicative of an active infection against one or more Leptospira serotypes. A Microscopic Agglutination Test (MAT) is the "gold standard" in detecting specific anti-Leptospira antibodies [16] [17] [18].

This study's objective was to determine the prevalence of anti-Leptospira antibodies to 13 serotypes in dogs captured in four zones of Mexico City, contained within the corresponding Canine Control Centers and analyze variables associated with the studied animals.

\section{Material \& Methods}

\subsection{Study Universe}

A descriptive study was performed in February and March 2014, to determine the pre- 
valence of different Leptospira serotypes on Mexico City's stray dog population. Blood samples were collected from dogs confined to four Canine Control Centers (CCC) in the districts of Coyoacan, Iztapalapa, Iztacalco and Benito Juarez, without discriminating for age, breed or sex. The subjects were divided into three age groups to analyze the results: Group 1, less than a year old, Group 2, 1 to 6 years, and Group 3, more than 6 years. The animals' age was calculated through their dental development according to the criteria provided in the odontogram CANINE [19].

\subsection{Blood Sample Acquisition}

Five milliliters of blood were taken from each animal by venipuncture and collected in sterile tubes without anticlotting agents. The serum was separated by centrifuging at $500 \mathrm{~g}$ for $10 \mathrm{~min}$, and stored at $4^{\circ} \mathrm{C}$ until analyzed.

\subsection{Immunology Test}

The sera were analyzed using a MAT test; the internationally referenced technique for the detection of anti-Leptospira specific antibodies, to which the diagnostic sensitivity and accurateness of the other techniques are compared and evaluated [14] [16] [18]. The test was standardized with the different antigens. Sera were considered positive when presenting agglutination at a dilution titer of 1:100 or higher.

\subsection{Antigens}

The antigens used corresponded to the following serotypes and strains: Icterohaemorrhagiae (RGA), Grippotyphosa (Moskva V), Canicola (Hond Utrecht IV), Bratislava (Jez Bratislava), Pomona (Pomona), Tarassovi (Perepelicin), Wolffi (3707), Hardjo (Hardjoprajitno LT 1085), Pyrogenes (Salinem), Icterohaemorrhagiae (Palo Alto), Portlandvere (Sinaloa ACR), Hardjo (Hardjoprajitno H-89). The last three were isolated in Mexico.

\subsection{Statistical Analysis}

Data were analyzed using SPSS and JMP 5.1 software. The association between the different variables and sero positivity was carried out using a chi-squared test.

\section{Results}

The 117 samples were collected from canines confined to the CCC of Coyoacan, 38; Iztapalapa, 34; Iztacalco, 31; and B. Juarez, 14.in Mexico City. The average age was 45 months (2.69 SE) with a range from 0.25 to 120 months; 61 (52\%) males and 56 (48\%) females. When distributed according to age groups, 28 were younger than a year (Group 1), 75 between 1 and 6 years (Group 2), and 14 were older than 6 years (Group 3).

Of the sera, $28.2 \%(33 / 117)$ were positive; $74 \%$ of the positive sera coagglutinated with two or more serotypes. Table 1 shows the results of the dilution titers obtained for the Leptospira antigens using the MAT technique for the 117 serums analyzed. The first 
Table 1. Dilution titers obtained using MAT for 13 Leptospira serotypes in the 117 canine sera obtained in Mexico City.

\begin{tabular}{|c|c|c|c|c|c|c|c|c|}
\hline \multicolumn{9}{|c|}{ Dilution Titers } \\
\hline Serotypes and Strains & 100 & 200 & 400 & 800 & 1600 & 3200 & Total & $\%$ \\
\hline Icterohaemorrhagiae (RGA) & 5 & 3 & 1 & - & - & - & 9 & 12.1 \\
\hline Icterohaemorragiae (Palo Alto) ${ }^{\mathrm{a}}$ & 7 & 8 & - & - & - & - & 15 & 20.3 \\
\hline Pyrogenes (Salinem) & 1 & 4 & - & - & - & 1 & 6 & 8.1 \\
\hline Griptotyphosa (Moska V) & - & 1 & - & - & - & - & 1 & 1.4 \\
\hline Canicola (Hond Utrech IV) & 5 & 10 & 2 & 1 & - & 2 & 20 & 27.0 \\
\hline Pomona (Pomona) & - & - & - & - & - & - & 0 & 0 \\
\hline Hardjo (Hardjo-bovis LT1085) & 1 & - & - & - & - & - & 1 & 1.4 \\
\hline Hardjo (Hardjoprajitno) & - & - & - & - & - & - & 0 & 0 \\
\hline Hardio (hardioprajino H-89) ${ }^{b}$ & 1 & - & - & - & - & - & 1 & 1.4 \\
\hline Wolffi (3705) & 2 & - & - & - & - & - & 2 & 2.7 \\
\hline Tarassovi (Perepelicin) & - & - & - & - & - & - & 0 & 0 \\
\hline Bratislava (Jesbratislava) & 6 & - & 1 & - & 1 & - & 8 & 10.8 \\
\hline Portland-vere (Sinaloa-ACR) ${ }^{c}$ & 10 & - & 1 & - & - & - & 11 & 14.8 \\
\hline Total & 38 & 26 & 5 & 1 & 1 & 3 & 74 & 100.00 \\
\hline$(\%)$ & $(32.4)$ & $(22.2)$ & $(4.2)$ & (0.8) & $(0.8)$ & $(2.5)$ & $(63.2)$ & \\
\hline
\end{tabular}

${ }^{\text {aS }}$ erotype Icterohaemorrhagiae (Palo Alto strain) isolated in Mexico; ${ }^{b}$ Serotype Harjo Hardjoprajitno (H-89 strain) isolated in Mexico; 'Serotype Portland-vere (Sinaloa-ACR strain) isolated in Mexico.

column shows the Leptospira serotypes and strains used in the study. The serotypes with the highest percentage of seropositivity were: Canicola, 27\%; Icterohaemorrhagiae (Palo Alto), 20.3\%; Portland-vere (Sinaloa ACR), 14.8\%; Icterohaemorrhagie (RGA), 12.1\%; and Bratislava, $10.8 \%$. There were also five sera with very high dilution titers, suggesting active infection. One reacted with the Canicola serotype at a 1:800 titer, another with Bratislava, 1:1600; and three sera at a 1:3200 titer, one reacted with Pyrogenes and two with Canicola. These three serotypes: Canicola, Pyrogenes, and Bratislava were found to be statistically significant $(\mathrm{p}<0.001)$.

Table 2 shows the sera that were seropositive to the different serotypes and Leptospira strains by study area. The samples obtained in the districts of Coyoacan, Iztapalapa and Iztacalco resulted seropositive to 10 serotypes and 66 coagglutinations. In Iztapalapa, 9 serotypes and 27 coagglutinations were detected, with Canicola as the prevalent serotype as in Coyoacan and Iztacalco. The serotypes that were identified in the four study areas were: Pyrogenes, Canicola Portland-vere and Icterohaemorrhagiae (Palo Alto), whilst Pomona and Hardjo (Hardjoprajitno) resulted negative. The most frequent coagglutinations pattern in the same animal was Canicola-Icterohaemorrhagiae (Palo Alto) $(\mathrm{n}=13)$ followed by Canicola-Portland-vere (Sinaloa ACR) $(\mathrm{n}=10)$, and Portland-vere (Sinaloa ACR)-Icterohaemorrhagiae (Palo Alto) $(\mathrm{n}=10)$. 
Table 3 shows the distribution of the positive sera to the different serotypes according to age group and study area. The presence of anti-Leptospira antigens in Group 2's (between 1 and 6 years old) sera was statistically significant $(\mathrm{p}=0.0001)$. The largest percentage, $75.8 \%$, of seropositive dogs was found in this age group $(25 / 33)$.

Table 2. Sero positivity to Leptospira serotypes from the 117 canine sera obtained in Mexico City according the study area.

\begin{tabular}{|c|c|c|c|c|c|c|}
\hline \multirow[b]{2}{*}{ Serotypes and strains } & \multicolumn{4}{|c|}{ StudyArea } & \multicolumn{2}{|c|}{ Total reactions } \\
\hline & $\begin{array}{c}\text { Coyoacán } \\
(\mathrm{n}=38) \\
\text { positives }\end{array}$ & $\begin{array}{c}\text { Iztapalapa } \\
(\mathrm{n}=34) \\
\text { positives }\end{array}$ & $\begin{array}{c}\text { Iztacalco } \\
(\mathrm{n}=31) \\
\text { positives }\end{array}$ & $\begin{array}{l}\text { B. Juárez } \\
(\mathrm{n}=14) \\
\text { positives }\end{array}$ & $\begin{array}{c}\text { Total } \\
(\mathrm{n}=117) \\
\text { positives }\end{array}$ & $\%$ \\
\hline Icterohaemorrhagiae (RGA) & 2 & 4 & 3 & 0 & 9 & 12.1 \\
\hline Icterohaemorrhagiae (Palo Alto) ${ }^{\mathrm{a}}$ & 5 & 5 & 2 & 3 & 15 & 20.3 \\
\hline Pyrogenes (Salinem) & 3 & 1 & 1 & 1 & 6 & 8.1 \\
\hline Griptotyphosa (Moska V) & 0 & 0 & 1 & 0 & 1 & 1.4 \\
\hline Canicola (HondUtrech IV) & 7 & 6 & 5 & 2 & 20 & 27 \\
\hline Pomona (Pomona) & 0 & 0 & 0 & 0 & 0 & 0.0 \\
\hline Hardjo (Hardjo-bovis LT1085) & 0 & 1 & 0 & 0 & 1 & 1.4 \\
\hline Hardjo (Hardjoprajitno) & 0 & 0 & 0 & 0 & 0 & 0 \\
\hline Hardio (hardioprajino H-89) ${ }^{b}$ & 0 & 1 & 0 & 0 & 1 & 1.4 \\
\hline Wolffi (3705) & 0 & 2 & 0 & 0 & 2 & 2.7 \\
\hline Tarassovi (Perepelicin) & 0 & 0 & 0 & 0 & 0 & 0 \\
\hline Bratislava (Jes Bratislava) & 3 & 3 & 2 & 0 & 8 & 10.8 \\
\hline Portland-vere (Sinaloa-ACR) ${ }^{c}$ & 4 & 4 & 1 & 2 & 11 & 14.8 \\
\hline Total & 25 & 27 & 14 & 8 & 74 & 100.0 \\
\hline$(\%)$ & $(65.7 \%)$ & $(79.4 \%)$ & $(45.1)$ & $(57.1)$ & $(63.2 \%)$ & \\
\hline
\end{tabular}

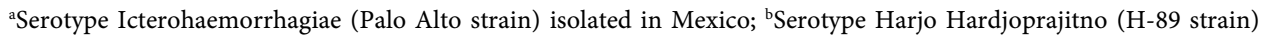
isolated in Mexico; 'Serotype Portland-vere (Sinaloa-ACR strain) isolated in Mexico.

Table 3. Distribution of $L$. interrogans seropositive dogs by age group and study area. In Mexico City.

\begin{tabular}{ccccccc}
\hline & \multicolumn{5}{c}{ Studyáreas } \\
StudyGroups & Coyoacán & Iztapalapa & Iztacalco & B. Juárez & Total & $\%$ \\
\cline { 2 - 7 } & 1 & 2 & 1 & 0 & 4 & 12.1 \\
Group 1 & 9 & 8 & 6 & 2 & 25 & 75.8 \\
Group 2 & 0 & 2 & 1 & 1 & 4 & 12.1 \\
Group 3 & 10 & 12 & 8 & 3 & 33 & 100 \\
Total & $(30.3)$ & $(36.3)$ & $(24.2)$ & $(9)$ & $(100)$ & \\
$(\%)$ & 10 & & &
\end{tabular}

${ }^{*}$ Group 1) $\leq 1$ year; Group 2) 1 to 6 years; Group 3) > 6 years. 


\section{Discussion}

Little attention has been shown towards leptospirosis, a zoonotic disease, in the metropolitan area of Mexico City, mostly due to the fact that the disease is considered to present itself predominantly in rural areas. However, the $28.2 \%$ of seropositivity that was demonstrated by this study is indicative of leptospirosis beginning to circulate among the stray dog population of the metropolis, presenting a significant public health risk. A risk that is intensified in the district of Iztapalapa, where seropositivity was present for 9 of the 13 serotypes included in this study.

The percentage obtained by this study is consistent with the $22 \%$ reported by Moles [20] in a study carried out on dogs in Iztapalapa, nevertheless, this percentage is lower than the $76.6 \%$ reported by Cisneros [21] for canines in the same district. This disparity in frequencies could be related to the canine population type researched and/or the time of year when the studies were carried out. Leptospira is considered to be a seasonal zoonosis with higher incidence during the rainy season, a factor that should be considered when presenting a clinical case [15] [22] [23] report an average seropositivity level of $30.5 \%$ in a longitudinal study performed in three seasons in which the following seropositivity data were obtained: $41.4 \%$ in spring, $33.9 \%$ in summer, and $25.2 \%$ in autumn, with Canicola and Icterohaemorrhagiae as the most frequently found serotypes [22]. The present study was performed in winter; hence, it was considered that the obtained percentage would be related to the climatological characteristics of Mexico City during this season.

The most frequent serotypes in this study were Canicola and Icterohaemorrhagiae with some sera presenting dilution titers of 1:600 and 1:3200, respectively. Both are mentioned in the literature as the dominant serotypes in urban environments [3] [7] [10] [12] [17]. However, our results indicate that the Portland-vere, a serotype included in the Canicola serotype, is becoming an important serotype in the canine population of Mexico City.

According to Adesiyuncriteria [11], for determining leptospirosis infection, 5 dogs with dilution titers between 1:800 and 1:3200 at the moment of the study coursed with acute leptospirosis, and leptospipuria could contaminate their surroundings, facilitating the disease's transmission to other mammals, such as rats, dogs and even humans. The same authors mention that low titers of 1:100 and 1:200 are considered to be indicative of immunological anamnesis due to a previous infection of the animal. The importance of performing seroepidemiological studies in open population, is that the evaluation of the serology among several individuals, includes a low cost strategy and exhibit the experience of the contact between the host studied and parasite antigens.

Llamas et al., 1991 [24] comment that the most frequent coagglutination is found between Canicola and Icterohaemorrhagiae serotypes. The Canicola-Icterohaemorrhagiae (Palo Alto) coagglutination was also the most common pattern found in this study, along with Canicola-Portland-vere (Sinaloa ACR).

It is worth mentioning that the highest number of seropositive animals to the different Leptospira serotypes was found in the district of Iztapalapa, where the highest 
agglutination titers corresponded to Canicola. This serotype is especially prevalent in urban areas where regular contact between stray dogs occurs. This result is perhaps related to the fact that this area holds the largest food supply market in the metropolitan area of Mexico City, where the continuous arrival of trucks filled with all sorts of food from the country's interior could foster the transport of leptospirosis infected rodents with the Hardjo (Hardjobovis), Hardjo (Hardjoprajitno) and Wolffi serotypes which all gave negative results in the sera obtained from the districts of Coyoacan, Iztacalco and B. Juarez. In addition to this, the immense amount of trash and food waste that is produced daily leads to the spread of mice and rats, as well as a high concentration of canine population. In which asymptomatic dogs have a relevant epidemiological role, as they are the main disseminators and contaminants of the soil and water with their urine. As known, the major source of human infection is the direct exposure to the infected animals' urine or contact with water and/or soil contaminated with urine; thus, municipal cleaning personnel, longshoremen, dairy farmers, butchers, refrigeration and sewage workers, among others, are the populations most likely to become infected in this district. On the other hand, the authors emphasize the epidemiological importance of knowing each of the different sero groups of the different Leptospira serovarieties, as well as local isolations [12] [25] [26] [27]. In this investigation, the most frequent sero groups were Canicola, which includes the Portland-vere (Sinaloa ACR) serotype, and the Icterohaemorrhagiae, which includes the Palo Alto and RGA strains. The importance of reporting the local isolations consists in the fact that they need to be considered when designing the regional strategies for leptospirosis vaccination.

The animals' age is an important factor in the dissemination and transmission of leptospirosis, as young animals are the most vulnerable to acquiring the disease. Therefore, it is important to highlight the amount of seropositive animals in Group 2, where the study's most statistically significant result was found ( $\mathrm{p}<0.001)$. The animal's reproductive age and the Leptospira seropositivity are possibly related to sniffing habits and the licking of external genitalia by infected males and females in heat [14] [21]. However, older dogs are more likely to have been exposed to leptospirosis at some point and, therefore, are likely to present antibodies for different serotypes due to immunological anamnesis [11].

The percentage of serological positivity to Leptospira antigens obtained in this study indicates that Leptospira is being transmitted among the canine population analyzed with a consequential risk to public health, as Rubel [28], reported in 1997, and pointed out that stray dogs are the number one factor for the transmission of human leptospirosis, and that the frequent contamination on the streets and infected animals' urine puddles constitute a microenvironment that is favorable for the survival of some Leptospira serotypes.

In Mexico, leptospirosis prevention and control requires cooperative action from the public, private, and social sectors, by means of advocating health, medical attention, basic sanitation, and training medical and epidemiologic personnel [16]. It is recommended to take advantage of the financial and human resources being employed for the 
current campaign for anti-rabies vaccination, to design and apply vaccines against canine leptospirosis keeping the serotypes identified in our population in mind [12]. It is necessary to develop informational programs about this disease. Veterinarian clinics and hospitals, as well as animal shelters and pet stores, among others, are the spaces where an anti-leptospirosis vaccine should be mandatorily applied and where veterinarians play an important role in educating the community about this zoonosis [29]

The epidemiological studies allow the improvement of prevention measures and control programs in order to favour the eradication of zoonotic diseases in human and animal populations.

\section{Conflict of Interest Statement}

The authors declare that they have no conflict of interest.

\section{References}

[1] Goldstein, R., Lin, R., Langston, C., Scrivani, P., Erb, H. and Barr, S. (2006) Influence of Infecting Serogroup on Clinical Features of Leptospirosis in Dogs. Journal of Veterinary Internal Medicine, 20, 489-494. https://doi.org/10.1111/j.1939-1676.2006.tb02886.x

[2] Moore, G., Guptill, L., Glickman, N., Caldanaro, R., Aucoin, D. and Glickman, L. (2006) Canine Leptospirosis, United States, 2002-2004. Emergency Infectious Disease, 12, 501-503. https://doi.org/10.3201/eid1203.050809

[3] Geisen, V., Stengel, C., Brem, S., Muller, W., Greene, C. and Hartmenn, K. (2007) Canine Leptospirosis Infections-Clinical Signs and Outcome with Different Suspected Leptospira Serogroups (42 Cases). Journal of Small Animal Practice, 48, 324-328. https://doi.org/10.1111/j.1748-5827.2007.00324.x

[4] Carmona-Gasca, C., León, L., Castillo-Sánchez, J., Ramírez-Ortega, J., Ko, A., Luna, C. And Peña-Moctezuma, A. (2011) Detection of Leptospira santarosai and L. kirschneri in Cattle: New Isolates with Potential Impact in Bovine Production and Public Health. Veterinaria México, 42, 277-288.

[5] García-González, R., Reyes-Torres, A., Basilio, D., Ramírez-Pérez, M. and Rivas-Sánchez, B. (2013) Leptospirosis; un problema de salud pública. Revista Latinoamericana de Patología Clinica, 60, 57-70.

[6] Sepúlveda, M., Santiago, D. and Preciado, R. (2002) La rata y el perro, importantes vectores de la leptospirosis en explotaciones pecuarias de Cd. Guzmán, Jalisco. Revista Cubanade Medicina Tropical, 54, 1-23.

[7] Stokes, J.E., Kaneene, J.B., Schall, W.D., Kruger, J.M., Miller, R.A., Kaiser, L. and Bolin, C.A. (2007) Prevalence of Serum Antibodies against Six Leptospira Serovars in Healthy Dogs. Journal of the American Veterinary Medical Association, 230, 1657-1664. https://doi.org/10.2460/javma.230.11.1657

[8] Scanziani, E., Origgi, F., Giusti, A., Iacchia, G., Vasino, A., Pirovano, G., Scarpa, P. and Tagliabue, S. (2002) Serological Survey of Leptospiral Infection in Kenneled Dogs in Italy. Journal of Small Animal Practice, 43, 154-157. https://doi.org/10.1111/j.1748-5827.2002.tb00048.x

[9] Blazius, R., Romao, P., Blazius, E. and da Silva, O. (2005) Occurrence of Leptospira spp. Seropositive Stray Dogs in Itapema, Santa Catarina, Brazil. Cadernos Saude Publica, 21, 1952-1956. 
[10] Rodriguez, A., Ferro, B., Varona, M. and Santafe, M. (2004) Exposure to Leptospira in Stray Dogs in the City of Cali. Biomedica, 24, 291-295.

[11] Adesiyun, A., et al. (2006) Sero-Epidemiology of Canine Leptospirosis in Trinidad: Serovars, Implications for Vaccination and Public Health. Journal of Veterinary Medicine Series $B$, 53, 91-99.

[12] Prescott, J. (2008) Canine Leptospirosis in Canada: A Veterinarian's Perspective. Canadian Medical Association Journal, 178, 397-398. https://doi.org/10.1503/cmaj.071092

[13] Rivera, F., de la Peña, M., Roa, R. and Ordóñez, B. (1999) Seroprevalencia de la leptospirosis en perros callejeros del norte de la ciudad de México. Veterinaria México, 30, 105-107.

[14] Luna, A., Moles, C., Salazar, G., Nava, V. and Gavaldón, R. (2008) La Leptospirosis canina y su problemática en México. Revista de Salud Animal, 30, 1-11.

[15] Zúñiga, I., Baeza, B., Bernal, A., Muñoz, W. and Domínguez, M. (2011) Casos de leptospirosis posterior a la gran inundación en el Municipio de Centro, Estado de Tabasco, 2007. Enfermedades Infecciosas Microbiología, 31, 33-37.

[16] Lottersberger, J., Pauli, R. and Vanasco, N. (2002) Desarrollo y validación de un enzimoinmunoensayo para el diagnóstico de Leptospirosis bovina. Archivos de Medicina Veterinaria, 34, 89-95. https://doi.org/10.4067/S0301-732X2002000100009

[17] Saengjaruk, P., et al. (2002) Diagnosis of Human Leptospirosis by Monoclonal AntibodyBased Antigen Detection in Urine. Journal of Clinical Microbiology, 40, 480-489.

[18] World Health Organization (2008) Leptospirosis humana: Guía para el diagnóstico, vigilancia y control. Rio de Janeiro. Centro Panamericano de Fiebre Aftosa VP/OPS/OMS.

[19] The Merck Veterinary Manual (2008) Merck \& Co., Inc., Whitehouse Station, NJ.

[20] Moles, C., et al. (2004) Determinación de anticuerpos contra L. interrogans en perros callejeros y del Poniente de la Cd. de México. Memorias de la XL Reunión Nacional de Investigación Pecuaria, Mérida, Yuc. 1-90.

[21] Cisneros, P., Moles, C., Gavaldón, R., Lara, A. and Bolaños, G. (2002) Diagnóstico serológico de leptospirosis en perros callejeros capturados en el Área metropolitana. Memorias del XVIII Congreso Panamericano de Veterinaria, La Habana.

[22] Llamas, T., Moles, C. and Salomón, S. (1991) Detección de anticuerpos anti-leptospira en perros del sur de la ciudad de México. XXII Congreso Nacional de Microbiología, 21-24 mayo.J-110, 48.

[23] Geisen, C., Stengel, S., Brem, W., Müller, C., Greene, K. and Hartmann, K. (2007) Canine Leptospirosis Infections-Clinical Signs and Outcome with Different Suspected Leptospira Serogroups (42 Cases). Journal of Small Animal Practice, 48, 324-328. https://doi.org/10.1111/j.1748-5827.2007.00324.x

[24] Moles, C., Salomón, S. and Murguía, L. (1990) Estudio serológico para detectar anticuerpos contra Leptospirainterrogans en perros de la Ciudad de México. Memorias del XXI Congreso Nacional de Microbiología, Villahermosa, 39.

[25] Levett, P., Walton, D., Waterman, L., Withintong, C., Mathisonand, G. and Edwards, C. (1998) Surveillance of Leptospiral Carriage by Feral Rats in Barbados. West Indian Medical Journal, 47, 15-17.

[26] Hartskeerl, R., Collares-Pereira, M. and Ellis, W. (2011) Emergence, Control and Re-Emerging Leptospirosis: Dynamics of Infection in the Changing World. Clinical Microbiology and Infection, 17, 494-501. https://doi.org/10.1111/j.1469-0691.2011.03474.x

[27] Rodríguez-Vidigal, F., Vera-Tomé, A., Nogales-Muñoz, N., Muñoz-García, B. and Muñoz-Sanz, A. (2014) Leptospirosis en un área sanitaria del suroeste español. Revista Clínica Española, 214, 247-252. 
[28] Rubel, D., Seijo, A., Cernigoi, B., Viale, A. and Wisnivesky-Colli, C. (1997) Leptospira interrogans en una población canina del Gran Buenos Aires: Variables asociadas con la seropositividad. Revista Panamericana de Salud Pública., 2, 102-106.

https://doi.org/10.1590/S1020-49891997000800002

[29] Arteaga-Toncoso, G., et al. (2015) Seroprevalence and Risk Factors Associated with Within-Flock Transmission of Leptospira interrogans in Transhumant Farming Systems in Mexico. Epidemiology and Infection, 143, 2894-2902.

Submit or recommend next manuscript to SCIRP and we will provide best service for you:

Accepting pre-submission inquiries through Email, Facebook, LinkedIn, Twitter, etc.

A wide selection of journals (inclusive of 9 subjects, more than 200 journals)

Providing 24-hour high-quality service

User-friendly online submission system

Fair and swift peer-review system

Efficient typesetting and proofreading procedure

Display of the result of downloads and visits, as well as the number of cited articles

Maximum dissemination of your research work

Submit your manuscript at: http://papersubmission.scirp.org/

Or contact ojmm@scirp.org 